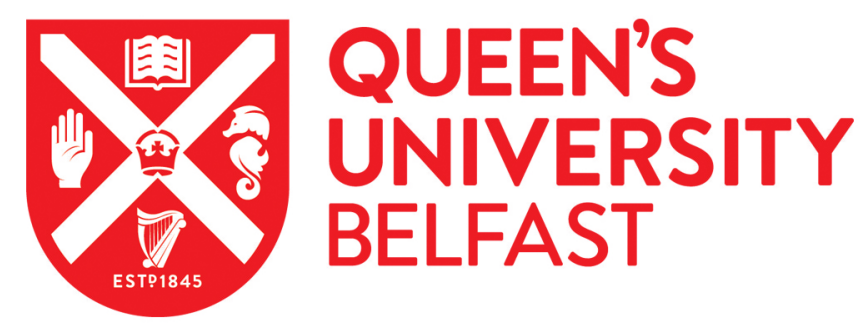

\title{
The Importance of Antenna Near-Field Losses in Intra-Body UHF Communication Applications
}

El-Saboni, Y., Conway, G., \& Scanlon, W. (2017). The Importance of Antenna Near-Field Losses in Intra-Body UHF Communication Applications. In 2017 IEEE International Symposium on Antennas and Propagation and USNC-URSI Radio Science Meeting (pp. 399-400). [3162] (IEEE International Symposium on Antennas and Propagation \& USNC/URSI National Radio Science Meeting: Proceedings). Institute of Electrical and Electronics Engineers Inc.. https://doi.org/10.1109/APUSNCURSINRSM.2017.8072242

Published in:

2017 IEEE International Symposium on Antennas and Propagation and USNC-URSI Radio Science Meeting

Document Version:

Peer reviewed version

Queen's University Belfast - Research Portal:

Link to publication record in Queen's University Belfast Research Portal

\author{
Publisher rights \\ (C) 2017 IEEE. \\ This work is made available online in accordance with the publisher's policies. Please refer to any applicable terms of use of the publisher.
}

General rights

Copyright for the publications made accessible via the Queen's University Belfast Research Portal is retained by the author(s) and / or other copyright owners and it is a condition of accessing these publications that users recognise and abide by the legal requirements associated with these rights.

Take down policy

The Research Portal is Queen's institutional repository that provides access to Queen's research output. Every effort has been made to ensure that content in the Research Portal does not infringe any person's rights, or applicable UK laws. If you discover content in the Research Portal that you believe breaches copyright or violates any law, please contact openaccess@qub.ac.uk. 


\title{
The Importance of Antenna Near-Field Losses in Intra-Body UHF Communication Applications
}

\author{
Yomna El-Saboni, Gareth A. Conway, William G. Scanlon \\ Centre for Wireless Innovation (CWI), ECIT Institute \\ Queen's University Belfast, BT3 9DT, UK \\ yelsaboni01@qub.ac.uk, g.conway@qub.ac.uk, w.scanlon@qub.ac.uk
}

\begin{abstract}
The gain of the intra-body propagation channel between tissue implanted antennas is largely dependent on the lossy tissue structures on the direct path between the nodes. Nonetheless, intra-body link performance may be improved through careful antenna design to minimize the near-field losses which are doubly important in this application. In an initial study we consider the effect of insulation on an implanted dipole antenna at the MedRadio band $(2.36-2.40 \mathrm{GHz})$ and placed within a muscle tissue phantom. Simulated electric field and radiation efficiency results are discussed for the single antenna case.
\end{abstract}

Keywords - Intra-body; implantable antennas; reactive nearfield losses; path gain.

\section{INTRODUCTION}

The performance of a UHF intra-body network (IBN) is not only related to the design of implanted antennas and their radiation characteristics, but it is also highly dependent on the through-tissue propagation environment that defines the inbody channel. Given the lossy nature of most body tissues at UHF, both the path length and the surrounding tissue structures and their characteristics are critical to link performance for any IBN application. However, the path between nodes in an IBN link is largely application dependent and may even change over time, for example, the link between the pectoral region and the abdomen as the host stands or sits. Therefore, IBN link performance optimization efforts should consider the implanted antennas, especially since there is an antenna at each end of the link and even a modest performance enhancement could have a significant effect on the application. In this initial simulation based study we focus on the coupling of the antenna with the body tissues in the near field with the aim of understanding the relative importance of losses local to the implanted antennas.

\section{ANTENNAS IN INTRA-BODY COMMUNICATION LINKS}

In [1] the authors presented simulated results for a $2.38 \mathrm{GHz}$ IBN within a multilayered tissue equivalent phantom. The main results from [1] are repeated in Fig. 1 which shows the path gain between two identical antennas with one at the center of a cylindrical three layer (muscle, fat, skin) phantom and the other within the various tissues along the cylinder radius. The most interesting result is that for all three antennas (un-insulated bow-tie, insulated bow-tie and insulated dipole), the path gain increases when one of the antennas is within the fat tissue. Given the identical simulation parameters (antenna, source and phantom models), the significant increase in forward path gain is solely due to the lower losses for each antenna type within the fat tissue $\left(\varepsilon_{r}=5.29\right.$ and $\left.\sigma=0.10 \mathrm{Sm}^{-1}\right)$. Another study [2] involved the simulation of the channel between two identical dipoles implanted in different homogenous body tissues. The study also looked at path loss versus distance and showed the effect of mutual coupling when the second antenna lies in the near field or the reactive zone. However, this study did not address the issue of near field antenna losses.

A biocompatible coating is necessary to protect an in-vivo antenna from body tissues and vice versa. Any medical device with an antenna has to be coated with a biocompatible layer to prevent any metallic oxidation which forms metal ions small enough to travel through the bloodstream and poison vital organs [3]. It is also well known that implant antenna performance is highly sensitive to the surrounding environment as the high water content tissue materials (e.g., skin and muscle) may cause a short-circuit effect [4]. Therefore, a biocompatible insulation is applied to implant antennas to jointly address these issues. Insulated antennas have the advantage of being less sensitive in terms of their current distribution to the dielectric properties of the surrounding medium [5]. Empirical testing was conducted in [6] to study the effect of implant antenna coatings and it was found that using an insulating layer helps reduce the discrepancy between simulation and measurements, presumably because of the importance of near field effects.

In this paper, we consider the effect of various thicknesses of insulation on an implanted dipole by examining the local electric field distribution and the overall performance as characterized by radiation efficiency associated with a simple muscle phantom.

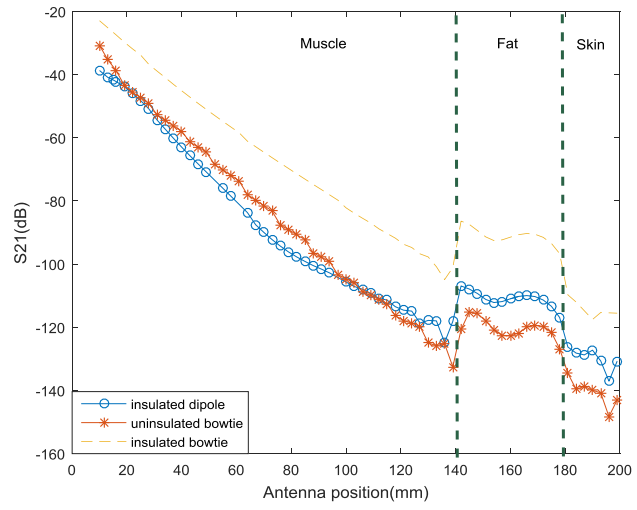

Fig 1 Comparison of effect of antenna type on the forward gain $\left(\left|S_{21}\right|\right)$ for the link between two IBN antennas within a multilayer phantom [1]. 


\section{NUMERICAL MODELING}

Simulations were performed in CST Microwave Studio $®$ for the MedRadio band (2.36-2.40 GHz) [7] using a cylindrical muscle tissue phantom ( $\varepsilon_{r}=52.8$ and $\sigma=1.69 \mathrm{Sm}^{-1}$ ) of height $140 \mathrm{~mm}$ and radius $70 \mathrm{~mm}$. An insulated dipole antenna, identical to that described in [1], with wire (PEC) radius of $0.6 \mathrm{~mm}$ and a total length of $55.3 \mathrm{~mm}$ was placed at the center of the phantom and oriented along the cylindrical axis (Z-axis). The antenna insulation layer was modelled as vacuum and was varied between $1.6 \mathrm{~mm}$ thickness (additional to the radius of the dipole antenna) to $27.2 \mathrm{~mm}$ with 17 simulation scenarios in total.

\section{RESULTS}

\section{A. Electric Field Distribution}

The electric field $\left(E_{z}\right)$ distribution close to the antenna in the axial plane of the cylindrical phantom is shown in Fig. 2. The plot compares different thicknesses of vacuum insulation. In Fig. 2(c) it is clear that there is strong near field interaction with the surrounding muscle tissues.

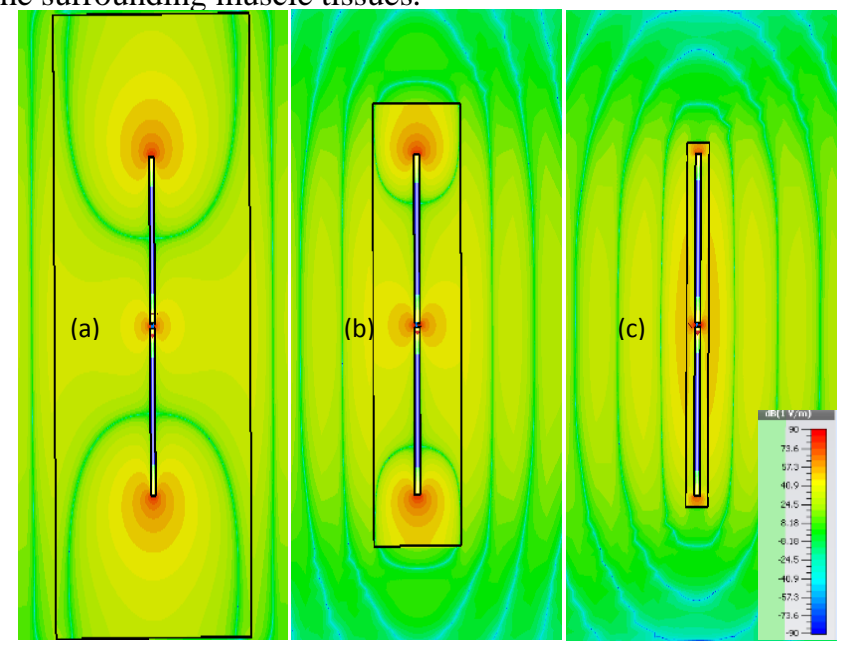

Fig 2 Electric field distribution for a dipole antenna within a muscle phantom with insulation thickness of (a) $22.4 \mathrm{~mm}$ (b) $8 \mathrm{~mm}$ and (c) $1.6 \mathrm{~mm}$.

\section{B. Radiation Efficiency}

Fig. 3 shows how the radiation efficiency for the dipole within the muscle phantom varies with insulation thickness. The efficiency has a log-linear slope of approximately $+5.4 \mathrm{~dB}$ per $\mathrm{cm}$ of additional insulation.

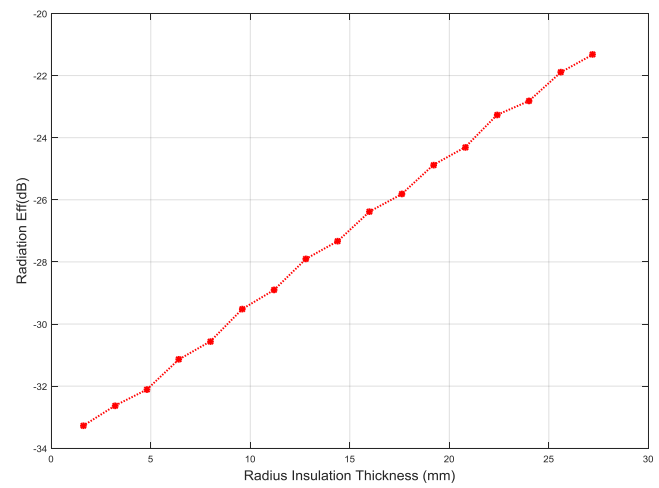

Fig 3 Effect of increasing insulation thickness on the implant antenna radiation efficiency.

\section{DISCUSSION AND RECOMMENDATIONS}

As expected the electric field distribution close to the tissue implanted antenna is significantly affected by the local material characteristics. At lower levels of insulation, the fields are shorted by the lossy muscle tissue, whereas the field behavior becomes more "dipole" like as the insulation increases. Furthermore, for lower levels of insulation the fields excited in the body tissues will lead to additional losses, irrespective of whether those fields are reactive or radiating. While the dipole is not appropriate for implant applications, the same principles would apply to any antenna design. Furthermore, many implant antenna designs are electrically small, especially given that implant device physical volume is restricted. This combined with the reality that insulation (biocompatible) layers are typically very thin means that careful near-field design is needed, especially where candidate antennas have strong reactive electric near fields. Additionally, the radiation efficiency results shown in Fig. 3 also confirm the impact of insulation on implant antenna performance. However, these preliminary results are not sufficiently informative to make strong conclusions. In particular, the current model has a fixed phantom size and larger insulation thicknesses also lead to shorter propagating paths through the muscle tissue which are also contributing to the higher radiation efficiency results. An improved simulation model may be able to separate out these effects in future studies.

\section{CONCLUSION}

This numerical study of implant antenna field distributions demonstrates the importance of insulation in antenna performance. Given that an intra-body link between implanted devices has an antenna at each end, there is additional benefit in optimizing antenna performance. However, further investigation needs to be conducted using different antenna types to validate the effect of isolating the near fields on the overall IBN link performance. Additionally, this analysis was conducted in the MEDradio band but it may be extended to other potential operating frequencies. Finally, the work should be experimentally validated in a suitable phantom test bed.

\section{REFERENCES}

[1] Y. El-Saboni, G. A. Conway, and W. G. Scanlon, "Effect of tissue boundaries on the intra-body communication channel at $2.38 \mathrm{GHz}$," in International Workshop on Antenna Technology (iWAT), 2017.

[2] D. Kurup, W. Joseph, G. Vermeeren, and L. Martens, "In-body Path Loss Model for Homogeneous Human Tissues," IEEE Trans. Electromagn. Compat., vol. 54, no. 3, pp. 556-564, Jun. 2012.

[3] F. Merli, B. Fuchs, J. R. Mosig, and A. K. Skrivervik, "The effect of insulating layers on the performance of implanted antennas," IEEE Trans. Antennas Propag., vol. 59, no. 1, pp. 21-31, Jan. 2011.

[4] J. Gemio, J. Parron, and J. Soler, "Human body effects on implantable antennas for ISM bands applications: models comparison and propagation losses study," Prog. Electromagn. Res., vol. 110, pp. 437-452, 2010.

[5] M. A. Hanson, et al., "Body area sensor networks: challenges and opportunities," Computer (Long. Beach. Calif)., vol. 42, no. 1, pp. 58-65, Jan. 2009.

[6] S.-M. Huang, M.-R. Tofighi, and A. Rosen, "Considerations for the design and placement of implantable annular slot antennas for intracranial pressure monitoring devices," IEEE Antennas Wirel. Propag. Lett., vol. 14, pp. 1514-1517, 2015.

[7] "Medical Device Radiocommunications Service (MedRadio) | Federal Communications Commission," Wireless Telecommunications, 2016. 